\title{
Alternative splicing enriched cDNA libraries identify breast cancer-associated transcripts
}

\author{
Elisa N Ferreira ${ }^{1,2}$, Maria CR Rangel', Pedro F Galante ${ }^{3}$, Jorge E de Souza ${ }^{3}$, Gustavo C Molina', Sandro J de Souza ${ }^{3}$, \\ Dirce M Carraro ${ }^{1 *}$ \\ From 5th International Conference of the Brazilian Association for Bioinformatics and Computational Biology \\ (X-meeting 2009) \\ Angra Dos Reis, RJ, Brazil. 18-22 October 2009
}

\begin{abstract}
Background: Alternative splicing (AS) is a central mechanism in the generation of genomic complexity and is a major contributor to transcriptome and proteome diversity. Alterations of the splicing process can lead to deregulation of crucial cellular processes and have been associated with a large spectrum of human diseases. Cancer-associated transcripts are potential molecular markers and may contribute to the development of more accurate diagnostic and prognostic methods and also serve as therapeutic targets. Alternative splicing-enriched cDNA libraries have been used to explore the variability generated by alternative splicing. In this study, by combining the use of trapping heteroduplexes and RNA amplification, we developed a powerful approach that enables transcriptome-wide exploration of the AS repertoire for identifying AS variants associated with breast tumor cells modulated by ERBB2 (HER-2/neu) oncogene expression.
\end{abstract}

Results: The human breast cell line (C5.2) and a pool of 5 ERBB2 over-expressing breast tumor samples were used independently for the construction of two AS-enriched libraries. In total, 2,048 partial cDNA sequences were obtained, revealing 214 alternative splicing sequence-enriched tags (ASSETs). A subset with 79 multiple exon ASSETs was compared to public databases and reported 138 different AS events. A high success rate of RT-PCR validation (94.5\%) was obtained, and 2 novel AS events were identified. The influence of ERBB2-mediated expression on AS regulation was evaluated by capillary electrophoresis and probe-ligation approaches in two mammary cell lines ( $\mathrm{Hb} 4 \mathrm{a}$ and $\mathrm{C5.2}$ ) expressing different levels of ERBB2. The relative expression balance between AS variants from 3 genes was differentially modulated by ERBB2 in this model system.

Conclusions: In this study, we presented a method for exploring AS from any RNA source in a transcriptome-wide format, which can be directly easily adapted to next generation sequencers. We identified AS transcripts that were differently modulated by ERBB2-mediated expression and that can be tested as molecular markers for breast cancer. Such a methodology will be useful for completely deciphering the cancer cell transcriptome diversity resulting from AS and for finding more precise molecular markers.

\section{Background}

More than 30 years ago, Gilbert predicted the existence of protein variants due to the alternative use of exon-intron borders in eukaryotic cells [1]. This prediction has been continually confirmed as a common

\footnotetext{
* Correspondence: dirce.carraro@hcancer.org.br

'Laboratory of Genomics and Molecular Biology, Hospital A.C. Camargo,

Fundação Antonio Prudente, São Paulo, 01509-900, Brazil

Full list of author information is available at the end of the article
}

feature of many species, including humans. Recent estimations, based on high-throughput sequencing, suggest that $90-95 \%$ of multiple-exon human genes undergo alternative splicing (AS) [2,3], producing an average of six distinct transcripts from each gene [4]. This phenomenon enormously impacts the repertoire of proteins, since $80 \%$ of AS events occur within the coding region [5], thus interfering in the functional aspects of the cells.
C Biomed Central

C 2010 Carraro et al; licensee BioMed Central Ltd. This is an open access article distributed under the terms of the Creative Commons Attribution License (http://creativecommons.org/licenses/by/2.0), which permits unrestricted use, distribution, and reproduction in any medium, provided the original work is properly cited. 
AS regulates important processes, such as embryonic development, cellular differentiation and apoptosis, by the generation of different protein isoforms among distinct tissues, developmental stages and pathological conditions [6-8]. Alterations of the splicing process, such as the loss of expression balance between variants and aberrant splicing, can lead to the deregulation of crucial cellular processes and are consequently associated with a large spectrum of human diseases [9], including cancer [10-12].

The development of methodologies to explore transcriptome diversity resulting from AS has been shown to be a potent tool, not only for improving the biological basis of cancer but also for searching for more precise molecular markers for diagnostic, prognostic and therapeutic purposes $[13,14]$. Different strategies for large-scale AS variant exploration have been used with different goals. Sequence and microarray-based approaches have been used for defining the AS repertoire of human cells. The former includes several computational analyses concerning genomic and transcriptome alignments of human ESTs (expressed sequence tags) and mRNA databases [11,15-17] and cross-species alignment from closely related organisms $[18,19]$; the latter includes genomic and exon-intron junction microarray platforms [20-23]. Both approaches have contributed to the investigation of the expression pattern of AS variants and also facilitated the identification of novel AS variants. Nonetheless, both approaches are impaired in detecting low-abundance AS transcripts. In this sense, AS-enriched cDNA libraries is one of the most interesting approaches because it combines the convenience of cDNA direct sequencing with the advantage of detecting low-abundance transcript variants. The methodology is based on one enrichment step, consisting of the trapping of heteroduplex molecules formed by the hybridization of two distinct AS variants from the same gene [24]. The heteroduplex can be captured by molecules that recognize the heteroduplex structure $[25,26]$, generating a vast number of AS events without previous knowledge of them. In this study, to explore AS variants associated with breast tumor cells, we established a powerful approach that enabled the direct exploration of an AS repertoire by combining the use of trapping heteroduplex and RNA amplification. To favor the trapping of splicing variants associated with breast tumor cells that over-expresses the ERBB2 (HER-2/neu) oncogene, a human breast cell line (C5.2) and a pool of 5 ERBB2 over-expressing breast tumor samples were used. Two AS-enriched libraries were constructed, generating a set of 2,048 partial cDNA sequences, named here as alternative splicing sequence-enriched tags (ASSETs), as suggested by Watahiki and collaborators [25]. A subset with 79 ASSETS representing distinct multiple exon sequences was explored in this analysis and reported 138 different AS events. A high rate of validation by RT-PCR (94.5\%) was obtained, and 2 novel AS events were identified. Moreover, the balance in the expression level of the AS variants from 3 genes was influenced by ERBB2-mediated expression.

The approach presented here certainly will contribute to the identification of the AS repertoire of cancer cells, especially as it is potentially applicable to any cell type from any tumor tissue, since a small amount of total RNA is required with no previous cDNA library construction. Furthermore, it is completely suitable for using with next-generation sequencers, substantially increasing its potential in deciphering the AS diversity in cancer cell transcriptome.

\section{Results}

\section{Alternative splicing libraries}

Two distinct AS libraries were constructed (Lib_1 and Lib_2) using $5 \mu \mathrm{g}$ of total RNA as the starting material. Library 1 (Lib_1) was prepared from the human breast cell line C5.2, which over-expresses the oncogene $E R B B 2$, and library 2 (Lib_2) was prepared from a pool of 5 invasive breast carcinoma samples that stained positively for ERBB2 according to immunohistochemistry analysis (Table 1).

The strategy for AS library construction was based on the methodology described by Watahiki and collaborators [25] with some modifications. One significant difference was the use of total RNA instead of parental full-length cDNA libraries, which simplifies the process and decreases costs. Another important adaptation was the inclusion of a RNA amplification procedure based on T7 RNA polymerase and Template Switch oligo (TSoligo) [27], which allows the use of small quantities of RNA (Figure 1 I-IV). The amplified RNA was converted into double-stranded cDNA (dscDNA) (Figure $1 \mathrm{~V}-\mathrm{VI}$ ), which was then submitted to denaturation and renaturation steps, promoting the formation of heteroduplex DNA molecules by the hybridization of complementary regions from two distinct splicing variants from the same gene (Figure $1 \mathrm{VII})$. The remaining single-stranded molecules or overhanging regions were removed with exonuclease VII treatment (Figure 1 VIII), whereas the double-stranded cDNA molecules were cleaved with the $D p n I I$ restriction enzyme (Figure 1 IX). This step resulted in double-stranded fragments, constituting homo- and heteroduplex molecules with cohesive ends to bind adaptors. The enrichment of the heteroduplex molecules occurred through the trapping of singlestranded loops by the annealing of random 25-mer biotinilated oligonucleotides captured by streptavidin magnetic particles (Figure $1 \mathrm{X}$ ). Complementary overhanging adaptors were then specifically ligated to the 
Table 1 Clinical characteristics from the ductal carcinoma samples

\begin{tabular}{|c|c|c|c|c|c|c|}
\hline Sample Name & Stage & Age & TNM & LN & Grade & Molecular Markers \\
\hline 9T & $\| \mathrm{ll}$ & 55 years & T2NOMO & Negative & Grade I SBR & ER +/ PR +/ p53 -/ ERBB2+ (3+) \\
\hline 20T & $\| b$ & 87 years & T2NOMO & Negative & Grade II SBR & $\mathrm{ER}+/ \mathrm{PR}$-/ p53 -/ ERBB2+ (3+) \\
\hline $22 \mathrm{~T}$ & $\| \mathrm{b}$ & 56 years & T2N1M0 & Positive & Grade III SBR & $\mathrm{ER}+/ \mathrm{PR}-/ \mathrm{p} 53$-/ ERBB2+ (2+/3+) \\
\hline $28 \mathrm{~T}$ & Illa & 42 years & $\mathrm{T} 2 \mathrm{~N} 2 \mathrm{M} 0$ & Positive & Grade II SBR & $\mathrm{ER}$ +/ PR -/ p53 -/ ERBB2+ (3+) \\
\hline 36T & । & 45 years & T1NOMO & Negative & Grade III SBR & $E R+/ P R$-/ p53 -/ ERBB2+ (3+) \\
\hline
\end{tabular}

Age: age of diagnosis; TNM: classification according to TNM (T - size; N - lymph node status; M - presence of metastasis); LN: involvement of sentinel lymph nodes; grade: grades I, II and III according to SBR; molecular markers: ER - estrogen receptor; PR - progesterone receptor; P53 - protein TP53; and ERBB2 protein ERBB2.

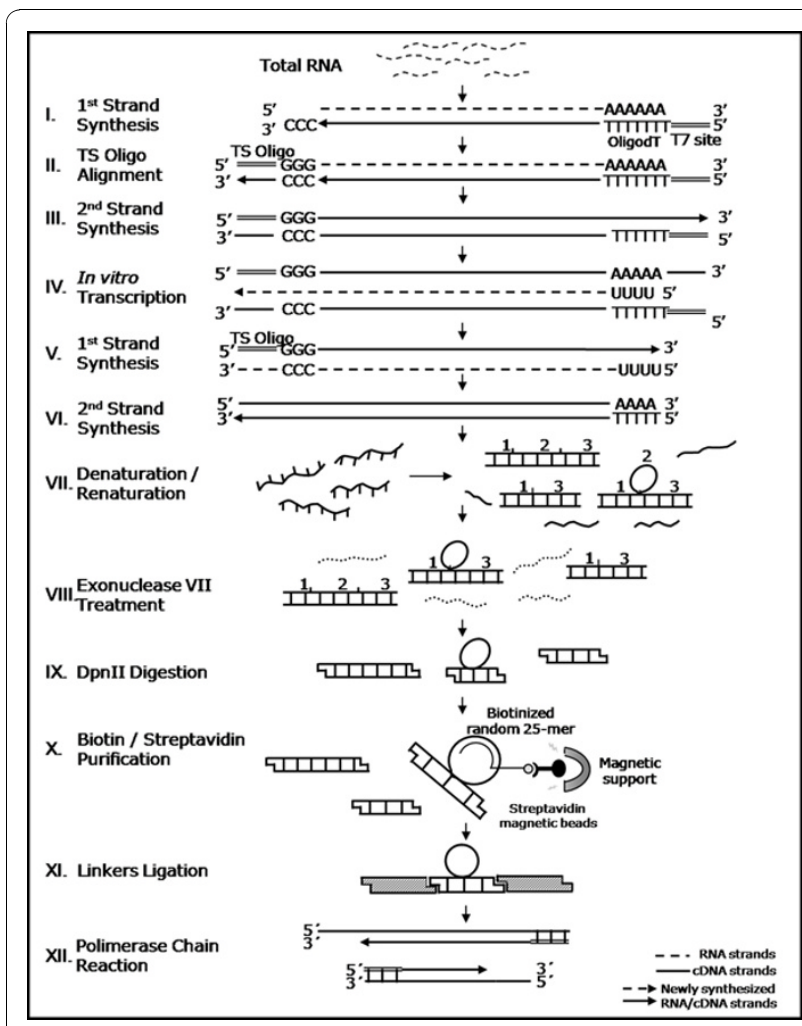

Figure 1 Schematic view of the alternative splicing library construction with amplification of RNA. I. Oligo dT containing T7 RNA Polymerase recognition site was used for first strand CDNA synthesis with Superscript II that adds cytosine residues after reaching the $5^{\circ}$ end of mRNAs. II. This c-rich region serves as anchor for TS-oligo alignment, allowing further polymerization to the end of the oligo. III. Second strand CDNA synthesis using TS-oligo. IV. Amplification of mRNA using T7 RNA Polymerase. V. First strand cDNA synthesis using TS-oligo. VI. Second strand cDNA synthesis using oligodT. VII. Denaturation and renaturation resulting in the formation of heteroduplexes molecules by common exons complementarity. VIII. Single-stranded molecules degraded by Exonuclease (dotted line). IX. Dpnll digestion resulting in small cohesive fragments. X. $25 \mathrm{mer}$ biotinilated random oligos coupled to streptavidin magnetic beads anneal to single-strand loops. XI. Coupling of specific adaptors to the cohesive ends of the captured heteroduplexes. XII. PCR amplification of fragments using adaptors specific oligos (double line). cohesive ends of the heteroduplex molecules (Figure 1 $\mathrm{XI}$ ), generating a recognition site for primer annealing and consequently allowing for PCR amplification (Figure $1 \mathrm{XII})$, cloning and sequencing.

A total of 2,048 high quality sequences (Phrep > 20) were generated from both libraries. Sequences from each library were clustered using the CAP3 program [28], resulting in 149 consensus sequences for library Lib_1 (96 contigs and 53 singlets) and 146 consensus sequences for library Lib_2 (74 contigs and 74 singlets) (Table 2 and Figure 2A). The number of consensus sequences obtained revealed, as expected, a high redundancy within the libraries (Table 2), since no normalization procedure was implemented in our approach.

All consensus sequences were then aligned to the human genome (NCBI build \#36.1) using BLAST [29] and Sim4 [30], where only the best hit was considered. Based on criteria for identity ( $\geq 93 \%)$ and coverage $(\geq$ $55 \%), 214$ consensus sequences were aligned on the human genome, 93 and 121 of them reporting multiple and one-exon(s) sequences, respectively (Figure $2 \mathrm{~B}$ ). The consensuses were termed ASSETs, as previously proposed $[25,26]$.

Furthermore, to check whether our library construction approach enables full-length representation, including the 5' end of transcripts, we verified the relative position of the ASSETs throughout the length of fulllengths (Figure 3). The analysis resulted in a similar representation of 3' and 5' ends with a slightly higher concentration of ASSETs in the central region, indicating that no bias were introduced towards higher representation of full transcript 3' ends. Additionally, the fact that the average size of mRNAs (RefSeq) represented by ASSETs in our libraries was of 2,836 nt, similar to the average size of all mRNA sequences from RefSeq

Table 2 Characterization of libraries Lib_1 and Lib_2

\begin{tabular}{lccccc}
\hline Library & $\begin{array}{c}\text { \# High Quality } \\
\text { Sequences }\end{array}$ & $\begin{array}{c}\# \\
\text { Contigs }\end{array}$ & $\begin{array}{c}\# \\
\text { Singlets }\end{array}$ & $\begin{array}{c}\# \\
\text { Consensus }\end{array}$ & Redundancy \\
\hline Lib_1 & 946 & 96 & 48 & 144 & $84.78 \%$ \\
Lib_2 & 1102 & 74 & 71 & 145 & $86.84 \%$ \\
Total & 2048 & 170 & 119 & 289 & - \\
\hline
\end{tabular}




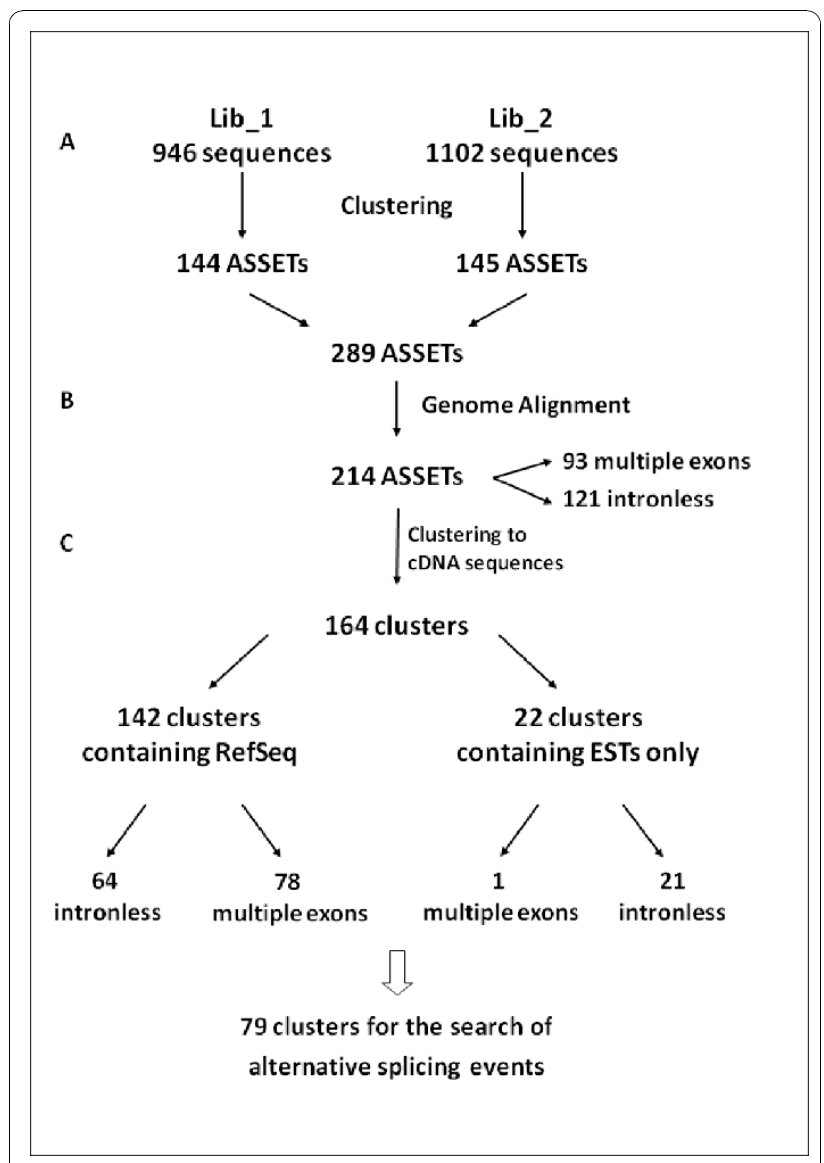

Figure 2 Flowchart of the bioinformatics pipeline.

database (3,098 nt) suggested no bias in representation of $5^{\prime}$ end from short transcripts (Figure 3).

\section{Detection of alternative splicing events}

No distinct splicing variants were observed among the sequences belonging to the same consensuses that would be indicative of putative AS events. Therefore, we searched for AS events through comparisons between ASSETs and full-length or partial cDNA sequences available in public databases.

First, ASSETs were clustered with ESTs from dbEST $(8,133,299$ ESTs), mRNAs (244,284 sequences) and RefSeqs (26,040 sequences) downloaded from UCSC (September 2007) (Figure 2C). This step resulted in 164 clusters, where 142 contained at least one RefSeq sequence. Sixteen clusters contained sequences from both libraries (Lib_1 and Lib_2), revealing an overlap of approximately $10 \%$.

The 79 clusters containing ASSETs with multiple exons were scanned for AS events through pairwise comparisons of exon/intron boundaries between the ASSET and the reference sequences of each cluster. AS events were searched within the region delimited by the two outermost overlapping regions of each ASSET related cluster. For each ASSET, the corresponding gene and the number and type of related alternative splicing events were annotated.

All 79 multiple exon ASSETs were considered known transcripts since they were represented by sequences at public databases. Moreover, for 39 out of 79 ASSETs (49.4\%), an alternatively spliced transcript was described in the public databases. For these 39 ASSETs, 138 AS events were detected, including intron retention (5.8\%), exon skipping (9.4\%), alternative splice site 3' (39.8\%) and alternative splice site 5' (44.9\%). The remaining 40 ASSETs, to which no AS event has been reported, may result from novel AS events not yet reported in public databases (Table 3). The intronless ASSETs were not used for the AS search, since it is not possible to identify the direction of transcripts in the absence of splice sites. Nonetheless, it is interesting to note that 63 out of 96 intronless sequences (65.6\%) aligned to regions involved in AS, according to public databases. This can be considered an indirect sign that these ASSETS are prone AS transcripts.

\section{Gene ontology annotation}

For exploring the functional aspects of the genes that harbor AS, the 142 ASSETs were classified within the biological process categories. Using BinGO tools [31], 11 categories revealed a statistically significant enrichment of genes (Table 4) and are represented in a hierarchical form in Figure 4. The most significantly enriched category was translation elongation, due to a great number of ribosomal proteins detected in our data.

\section{Validation of ASSETs and heteroduplexes}

Eighteen ASSETs were randomly selected for RT-PCR validation, including 6 and 7 ASSETs exclusively from Lib_1 and Lib_2, respectively and 5 ASSETs that were detected in both libraries. The validation process was performed in two steps: $i$. ASSET validation - to confirm the presence of the ASSET in the same RNA used for library construction and $i$. heteroduplex validation - to search for alternatively spliced transcripts that could have participated in the heteroduplex formation (Table 5). By using a pair of primers that aligned at the extremities of the ASSET sequence, all but one ASSET was validated (17 out of $18,94.4 \%$ validation rate). The 5 ASSETs identified by both libraries were validated in both templates. Secondly, for 6 (SFRS9, FLNA, ALDH3A2, PTPLA, RPS2 and TRIP6) out of the 17 validated ASSETs (35.3\%), an additional AS variant was identified that could have participated in the heteroduplex formation. Two out of 6 AS variants that were transcribed from the genes PTPLA and TRIP6, which 


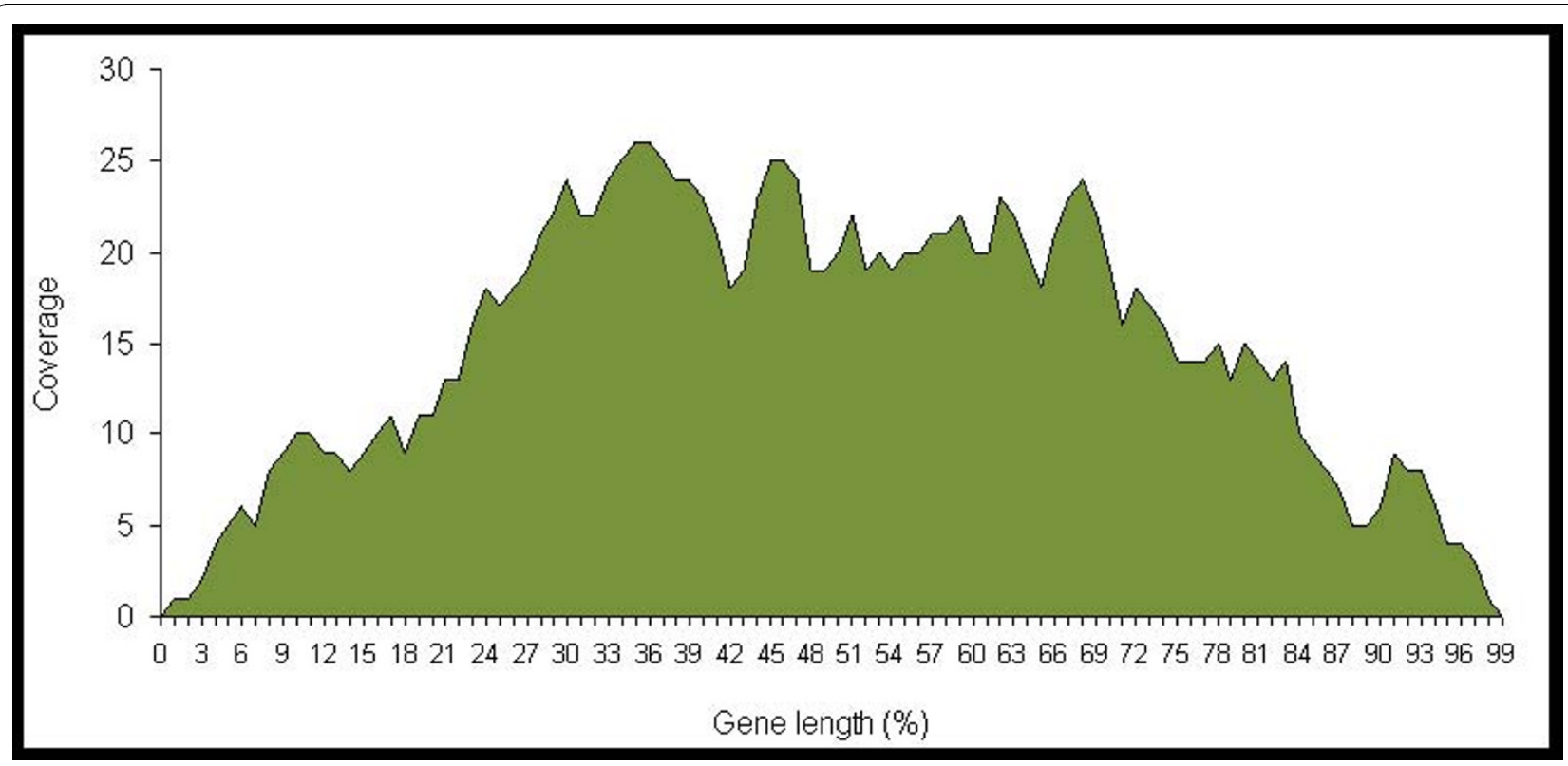

Figure 3 Relative position of the ASSETs throughout full-length mRNAs. The graphic represents the distribution of the ASSETs along corresponding transcript position. In the $x$-axis the relative transcript position is shown as a percentage value, where 0 indicates the $5^{\prime}$ end and 100 indicates the $3^{\prime}$ end. The coverage is the number of ASSETs aligning at each position.

were not described in public databases, are novel splicing variants. The lack of heteroduplex validation for the other 11 genes was probably due to a differential expression balance between splicing variants that precluded the amplification of one variant in favor of the most abundant one. The support for this assumption is that for 5 out of 11 (45.5\%) genes, an AS variant that could have participated in the heteroduplex formation was available in databases. For verifying whether the low level of overlap between both libraries was due to the low coverage in terms of the number of sequences generated for each library or due to the specific AS pattern of each RNA source used, we tested if the 13 ASSETs validated in cDNA from the corresponding library were also expressed in the cDNA from the other library. Four ASSETs from the 5 identified by Lib_1 were successfully amplified using the cDNA from the pool of the tumor samples (Lib_2). All 7 ASSETs from Lib_2 were successfully amplified using the cDNA from C5.2 (Lib_1), totaling $91.8 \%$ cross-validation (11 out of 12 ). The validation results are summarized in Table 5 .

\section{Novel alternative splicing: characterization of the putative isoforms}

The 2 novel AS variants were characterized regarding the putative corresponding protein isoform. The PTPLA gene [RefSeq:NM_014241.3] codes for the member $A$ of the protein tyrosine phosphatase-like family that contains proline instead of catalytic arginine. This gene contains 7 exons, and the AS variant detected in our study is due to the use of an alternative 5' splice site of intron 5 that elongates exon 5 by 117 nt (Figure 5A). All protein functional domains found for PTPLA were also present in the novel AS detected. However, in the novel AS variant, a premature stop codon was created $96 \mathrm{nt}$ upstream of the exon 5/exon 6 junction, probably leading to regulation by non-sense mediated decay (NMD) $[32,33]$.

The TRIP6 gene [RefSeq:NM_003302.2] is a thyroid hormone receptor interactor 6 that contains 9 exons. The novel alternatively spliced transcript reports retention of the last intron (Figure $5 \mathrm{~B}$ ). The protein coded by the TRIP6 gene localizes to focal adhesion sites and along actin stress fibers. The novel AS variant identified also inserts a premature stop codon in the putative coding protein, without interfering with any protein functional domain.

\section{Evaluation of AS variant regulation by ERBB2-mediated expression}

Finally, we investigated the putative influence of ERBB2mediated expression on the regulation of AS variants for 17 ASSETS validated using GAPDH as a normalization factor, by comparing the expression level of the ASSETs in the C5.2 cell line in relation to the ERBB2 basal expressed counterpart - the normal breast cell line (Hb4a) through capillary microfluidic electrophoresis (LabChip GX - Caliper Lifesciences) that accurately assesses the size and quantity of each amplification product [34]. 
Table 3 Search for AS variants by comparison with sequences from public databases

\begin{tabular}{|c|c|c|}
\hline & $\begin{array}{l}\text { Presence of alternatively } \\
\text { spliced transcripts in } \\
\text { databases }\end{array}$ & $\begin{array}{l}\text { No alternatively spliced } \\
\text { transcripts in databases }\end{array}$ \\
\hline \multirow[t]{22}{*}{ Lib_1 } & ATP1A1* & CDC42SE1 \\
\hline & ATP5A1 & CDK5RAP2* \\
\hline & C6orf108 & $D D B 2$ \\
\hline & CAMK2G & EEF2 \\
\hline & CD320 & FARS2 \\
\hline & CTSH & GABARAP \\
\hline & ELF3 & GNB3 \\
\hline & $F L N A^{*}$ & GRK6 \\
\hline & GAPDH & $H D A C 2$ \\
\hline & GNAS & ITGB5* \\
\hline & GNPTAB & MAN2A1 \\
\hline & MAN1B1 & OSBPL8 \\
\hline & NAP1L1 & PSMD6 \\
\hline & $P P I B$ & PTPRA \\
\hline & RANBP1 & 188268 \\
\hline & RPL28 & RBM10* \\
\hline & RPL6 & RNF149 \\
\hline & RPS4X & ROCK2 \\
\hline & SETD2 & RPL11 \\
\hline & SFRS9* & THSD1 \\
\hline & STK25 & \\
\hline & UQCRC1 & \\
\hline \multirow[t]{17}{*}{ Lib_2 } & $A L D H 3 A 2^{*}$ & $A C L Y$ \\
\hline & $A O F 2^{*}$ & ASCC3L1 \\
\hline & CCNB1 & C7orf55 \\
\hline & CREB3 & COL7A1* \\
\hline & DNAJC10 & DDEF1 \\
\hline & $F N 1^{*}$ & DENND4C \\
\hline & INTS9 & GDF9 \\
\hline & MYO1C & KIAA0090 \\
\hline & RPS2* & KIAA0152 \\
\hline & RPS5 & MRPL45 \\
\hline & SEC61G & PHF19 \\
\hline & ST13 & PTPLA* \\
\hline & & $R B M X$ \\
\hline & & SGSM2 \\
\hline & & SLC4A2 \\
\hline & & TRIP6* \\
\hline & & XPO1 \\
\hline \multirow{5}{*}{$\begin{array}{l}\text { Lib_1 } \\
\& \\
\text { Lib_2 }\end{array}$} & $C L T C^{*}$ & ATXN10 \\
\hline & $E I F 4 A 3^{*}$ & INPP1 \\
\hline & GSPT1* & PAIP1 \\
\hline & KRT18* & \\
\hline & PSMC2* & \\
\hline
\end{tabular}

*ASSETS selected for RT-PCR validation
For the 11 validated ASSETs, the relative expression levels were analyzed showing a slight influence of $E R B B 2$ over-expression in all ASSETs (ratio ranging from -1.9 to 1.4) (Supplemental Table 1).

For the 6 ASSETS presenting an additional AS variant, the putative influence of $E R B B 2$ over-expression in the relative expression balance of the pairs of distinct splicing variants (ASSET and additional AS) was evaluated in both cell lines. We first calculated the expression ratio from ASSET against the variant to each cDNA template and then compared the expression ratio between the C5.2 against Hb4a cell lines. For 3 out of 6 genes, a decrease in the expression balance of the ASSET and additional AS variants was identified between the tumor and normal cell lines (Figure 6; Table 6). In more detail, the ASSETs corresponding to SFRS9 [RefSeq: NM_003769.2] and FLNA [RefSeq: NM_001456.3] genes were stably expressed between cell lines, while the additional AS variants were more expressed in the C5.2 compared to Hb4a cell line (fold $=4$ and 3.5, respectively) leading to a decrease of 4.84 (SFRS9) and 4.78 (FLNA) in the expression balance between the splice variants (Table 6). The ASSET of the TRIP6 gene [RefSeq: NM_003302.2] was more expressed in the Hb4a than in the C5.2 (fold=4.6), whereas the additional AS variant presented no expression difference. These results suggested that ERBB2-mediated expression differently modulates the alternative splice variants of the genes SFRS9, FLNA and TRIP6. For the other 3 genes (RPS2, PTPLA and ALDH3A2), no difference in the expression balance of the AS variants between the cell lines was observed (Table 6).

To confirm the alteration in the relative expression balance of AS variants mediated by ERBB2 expression, a different approach based on probe-specific ligation and PCR amplification was applied [35]. In this strategy, 2 pairs of probes were designed for each gene, specifically targeting the variants of interest (Figure 6). The expression balance difference was confirmed for all 3 genes (FLNA, SFRS9 and TRIP6) visualized on the acrylamide gel (Figure 6).

\section{Discussion}

The diversity of the human transcriptional repertoire caused by AS has been extensively investigated [2,3], and it is agreed that its regulation is an important mechanism for physiological and pathological aspects of cells. Moreover, AS is a major contributor to protein diversity, which, in part, explains the high complexity of mammals compared to much simpler organisms containing a similar numbers of genes [5]. 
Table 4 Functional classification of genes within the statistically significant biological process categories

\begin{tabular}{|c|c|c|}
\hline GO-ID Description & $\begin{array}{l}\text { Corrected } p \\
\text { value }\end{array}$ & Gene Symbol \\
\hline Translation Elongation & $1.67 \mathrm{E}+01$ & RPL6 RPL21 EEF2 RPL11 RPS4X RPS2 RPS5 RPL28 \\
\hline $\begin{array}{l}\text { Intracellular Protein } \\
\text { Transport }\end{array}$ & $4.21 \mathrm{E}+01$ & XPO1 CLTC GABARAP KRT18 YWHAH NUP62 ZFYVE16 KPNA6 RPL11 MRPL45 SEC61G SEC61A1 SRP9 \\
\hline Intracellular Transport & $7.66 \mathrm{E}+01$ & $\begin{array}{l}\text { XPO1 MYO1C CLTC GABARAP YWHAH KRT18 NUP62 ZFYVE16 SEC22B KPNA6 RPL11 RANBP1 GNAS } \\
\text { MRPL45 SRP9 SEC61G SEC61A1 }\end{array}$ \\
\hline Cellular Localization & $2.55 \mathrm{E}+02$ & $\begin{array}{l}\text { XPO1 MYO1C VIL2 CLTC GABARAP YWHAH KRT18 NUP62 ZFYVE16 SEC22B KPNA6 GNAS RPL11 RANBP1 } \\
\text { MRPL45 SRP9 SEC61G SEC61A1 }\end{array}$ \\
\hline $\begin{array}{l}\text { Establishment of } \\
\text { Localization in Cell }\end{array}$ & $3.06 \mathrm{E}+02$ & $\begin{array}{l}\text { XPO1 MYO1C CLTC GABARAP YWHAH KRT18 NUP62 ZFYVE16 SEC22B KPNA6 RPL11 RANBP1 GNAS } \\
\text { MRPL45 SRP9 SEC61G SEC61A1 }\end{array}$ \\
\hline $\begin{array}{l}\text { Cellular Macromolecule } \\
\text { Metabolic Process }\end{array}$ & $3.81 \mathrm{E}+02$ & $\begin{array}{l}\text { PPP6C XPO1 UQCRC1 CAMK2G PTPLAD1 FARS2 DNAJC10 MAN1B1 RPS2 RPL6 PTPLA RPL11 PSMD6 } \\
\text { DNAJA3 GLT25D1 STK25 ROCK2 PAIP1 PTPRA ZDHHC7 AXL MOBKL1A EEF2 RPS4X RPS5 RPL28 IFNAR1 } \\
\text { CCNB1 MGAT1 ST13 SENP1 HDAC2 GSPT1 PPIB RPL21 PSMC2 DDB2 GRK6 MRPL45 CTSH }\end{array}$ \\
\hline Protein Targeting & $3.81 \mathrm{E}+02$ & XPO1 ZFYVE16 KPNA6 RPL11 GABARAP SRP9 SEC61G \\
\hline Protein Localization & $3.81 \mathrm{E}+02$ & $\begin{array}{l}\text { XPO1 VIL2 CLTC GABARAP YWHAH KRT18 NUP62 ZFYVE16 SEC22B KPNA6 RPL11 GNAS MRPL45 SEC61G } \\
\text { SEC61A1 SRP9 }\end{array}$ \\
\hline Translation Elongation & $3.81 \mathrm{E}+02$ & GSPT1 RPL6 RPL21 PAIP1 FARS2 EEF2 RPL11 RPS4X RPS2 MRPL45 RPS5 RPL28 \\
\hline Protein Transport & $3.81 \mathrm{E}+02$ & $\begin{array}{l}\text { XPO1 CLTC GABARAP YWHAH KRT18 NUP62 ZFYVE16 KPNA6 SEC22B RPL11 GNAS MRPL45 SEC61G } \\
\text { SEC61A1 SRP9 }\end{array}$ \\
\hline $\begin{array}{l}\text { Establishment of Protein } \\
\text { Localization }\end{array}$ & $3.81 \mathrm{E}+02$ & $\begin{array}{l}\text { XPO1 CLTC GABARAP YWHAH KRT18 NUP62 ZFYVE16 KPNA6 SEC22B RPL11 GNAS MRPL45 SEC61G } \\
\text { SEC61A1 SRP9 }\end{array}$ \\
\hline
\end{tabular}

Different approaches have been used to explore the variability caused by this phenomenon, and one of the most promising strategies is the use of AS enriched cDNA libraries $[25,26]$. This strategy does not require previous knowledge of the variants and permits an AS transcriptome-wide analysis.

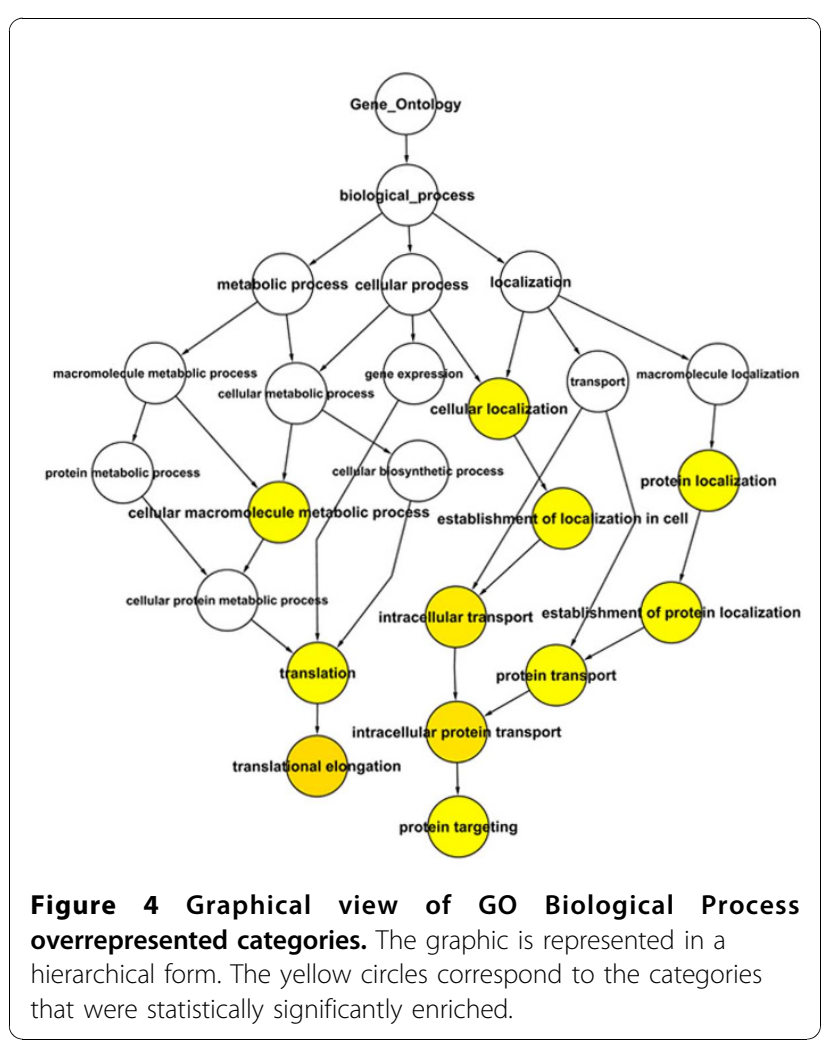

Deciphering of the human transcriptional repertoire related to AS variability is an enormous contribution in the comprehension of cancer and in the identification of more precise molecular markers in cancer.

Here we described an AS enriched cDNA library method by combining the use of trapping heteroduplex and RNA amplification procedures. The methodology was initially proposed by Watahiki and collaborators [25] and was applied in this study with some modifications to favor its application in clinically-oriented cancer studies, in which the availability of total RNA recovered from tumor tissues is normally restrictive. Moreover, the methodology established in this study is potentially applicable to RNA purified from a homogenous tumor cell population captured from a complex tissue by laser, which produces transcriptional data more correlated with the tumor cell.

Our strategy showed, in general, minimal artifacts in the identification of ASSETs, since our validation rate by RT-PCR was significantly high (94.5\%). Moreover, the fact that the great majority of the AS events found in our AS enriched libraries were present in public databases and that $100 \%$ of them harbor conserved splice sites strengths the assumption that we have established a robust methodology for identifying AS in a transcriptome-wide format.

The fact that we could confirm by RT-PCR novel alternatively spliced transcripts for 2 genes to which no AS variant was present in public databases is further support that among the ASSETs with no confirmation of AS events, a high frequency of prone additional AS 
Table 5 RT-PCR validation

\begin{tabular}{lcccc}
\hline Library Origin & Selected ASSETs & ASSET validation & Heteroduplex validation & Cross-validation \\
\hline Lib_1 & 6 & 5 & 2 & 4 \\
Lib_2 & 7 & 7 & 4 & 7 \\
Lib_1 \& Lib_2 & 5 & 5 & 0 & - \\
\hline
\end{tabular}

Library Origin: library where the ASSET was captured from; selected ASSETs: number of randomly selected ASSETs; ASSET validation: to confirm the presence of the ASSET in the same RNA used for library construction; heteroduplex validation: amplification of alternatively spliced transcripts that could have participated in the heteroduplex formation; and cross-validation: amplification of ASSETs specifically captured from one library using the cDNA template from the other library.

variants, which could participate in heteroduplex formation, is expected. The absence of amplification during the validation process of additional AS transcripts for two thirds of the selected genes suggests a significant difference in the expression level of both variants with consequent competition for the same pair of primers in the PCR reaction, avoiding the amplification of lowabundance AS transcripts.

The relatively high redundancy levels encountered in both libraries $(84.78 \%$ and $86.84 \%)$ were somewhat expected. This number is similar to the redundancy reported by Thill and collaborators [26]. In technical terms, this problem can be bypassed by decreasing the number of PCR cycles in the library construction, which is relatively easy to control.

Another potential problem was that no additional alternatively spliced transcripts were identified in sequence data provided by enriched cDNA libraries alone. This can be indicative of a problem caused by using non-phosphorylated adaptors. In this situation, only one strand $\left(5^{\prime}-3^{\prime}\right)$ of these adaptors was ligated to the 5' end of the DpnII digested molecules that contains a phosphate residue; the other strand $\left(3^{\prime}-5^{\prime}\right)$ was not ligated and, as a consequence, was disconnected from the cDNA molecules at the denaturation step of PCR and was consequently unable to be cloned and sequenced. Usually this region is re-synthesized by polymerase at the first cycle of the PCR reaction through annealing of complementary regions of cDNA molecules, a process known as polymerase fill-in, also seen in some cDNA library approaches [36,37]. However, in our case where the strands of cDNA molecules are from distinct alternatively spliced transcripts, the fill-in process is probably inefficient due to non-perfect annealing. To avoid this problem, the use of phosphorylated adaptors is a simple solution that would favor the representation of both alternatively spliced transcripts that formed the heteroduplex structure.

$E R B B 2$, or $H E R-2 / n e u$, is an oncogene that is overexpressed in $20-30 \%$ of human breast carcinomas and is associated with poor prognosis, independent of the lymph node status $[38,39]$. This marker is also associated with chemo resistance to a range of anticancer drugs and a positive response to herceptin [40,41]. Despite this oncogene being most extensively investigated in clinical and basic oncology, the ERBB2-mediated mechanism involved in the transformation and progression of breast tumors has not yet been totally elucidated.

In this study, we proposed to identify alternatively spliced transcripts associated with breast tumors that are under $E R B B 2$ influence by constructing 2 ASenriched cDNA libraries using RNA sources representative of $E R B B 2$ over-expression: the human breast cell line C5.2 that was previously transfected with 4 copies of full-length ERBB2 [42] and a pool of 5 breast carcinoma samples, which demonstrate strong positivity in ERBB2 immunostaining in tumor cell membranes [43].

For testing if the expression of ASSETs was regulated by $E R B B 2$-mediated expression, we evaluated the ASSETs validated by RT-PCR in both cell lines, HB4a and C5.2, the former with basal levels and the latter with over-expression of ERBB2 mRNA [44]. Both cell lines have been considered a model for the investigation of $E R B B 2$-mediated expression, since the only difference between them is the insertion of 4 copies of full-length $E R B B 2$ in the C5.2 cell line $[45,46]$. For the ASSETs in which we could identify an additional AS transcript by RT-PCR, $50 \%$ of them (3 out of 6 - TRIP6, FLNA and SFRS9) seemed to be influenced by ERBB2-mediated expression, since differences in the relative expression balance between both cell lines were observed.

Although the expression assessment of 2 or more AS variants is a problematic issue concerning accurate quantification the results presented here were confirmed by an alternative methodology, which increased the robustness of the data.

The microfluidic capillary electrophoresis-based strategy relies on amplification of both variants in the same reaction and could introduce bias due to amplification competition between variants. However, this would be expected to equally influence all reactions, independent of the template used. The alternative strategy relies on the specific binding of probes under highly stringent conditions, enabling the evaluation of each variant separately, with high accuracy and is consequently very promising for AS expression assessment. The different expression balance between both cell lines for 3 genes confirmed by 2 different approaches suggests that these genes transcribe AS variants, whose expression is differently influenced by $E R B B 2$. 


\section{A Genomic Coordinates}

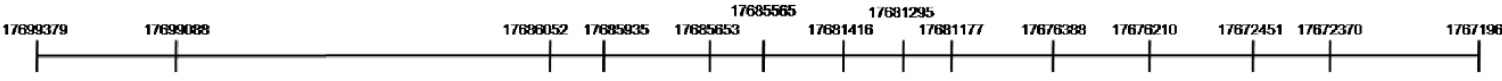

\section{Gene PTPLA}
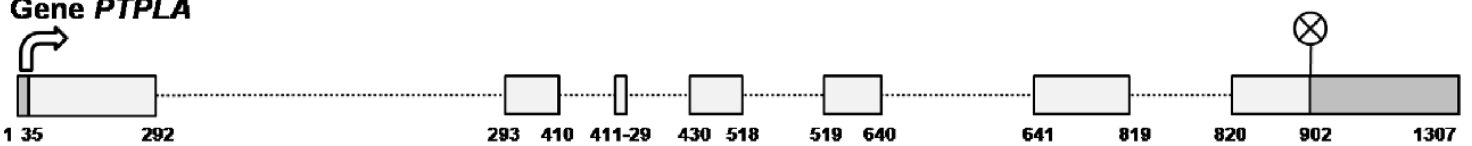

PTPLA Protein

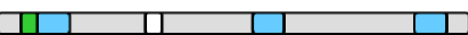

Novel Variant of PTPLA gene

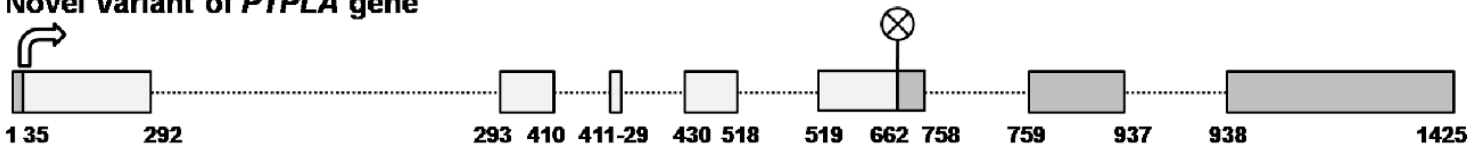

PTPLA Novel Isoform

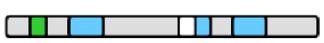

$\square$ Protein-Tyrosine Phosphatase-Like domain $\square$ Protein-Tyrosine Phosphatase, active site $\square$ Chaperonin, Cpn60, conserved site

$\square$ Transmembrane regions

\section{B Genomic Coordinates}

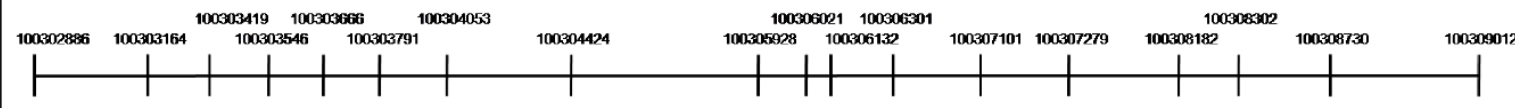

Gene TRIP6

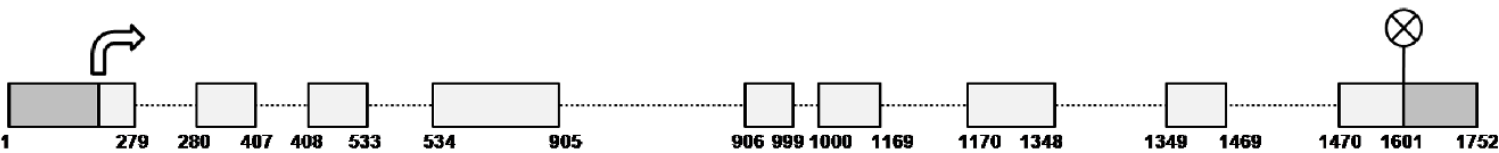

Novel Variant of TRIP6 gene

TRIP6 Protein

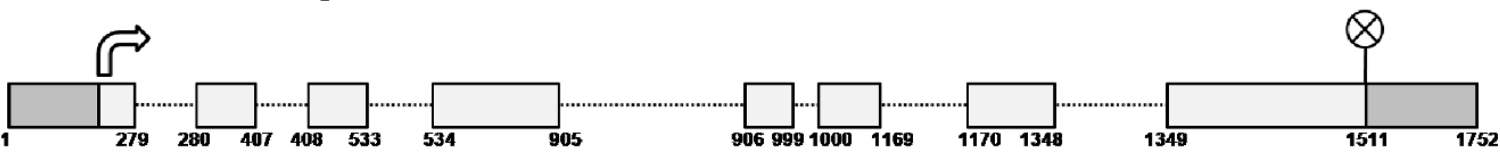

TRIP6 novel isoform

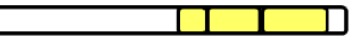

\section{$\vec{r}$ Translational Initiation Site $\bigotimes$ stop Codon}

Figure 5 Characterization of the novel AS variants identified. The scheme shows the genomic structure and protein domains of the known and putative novel variants. The squares represent the exons, and the lines represent the introns. The dark regions represent the $5^{\prime}$ and $3^{\prime}$ untranslated regions (UTR), the arrow represents the translational initiation site and the circles represent the stop codons. A - PTLA and B - TRIP6. 


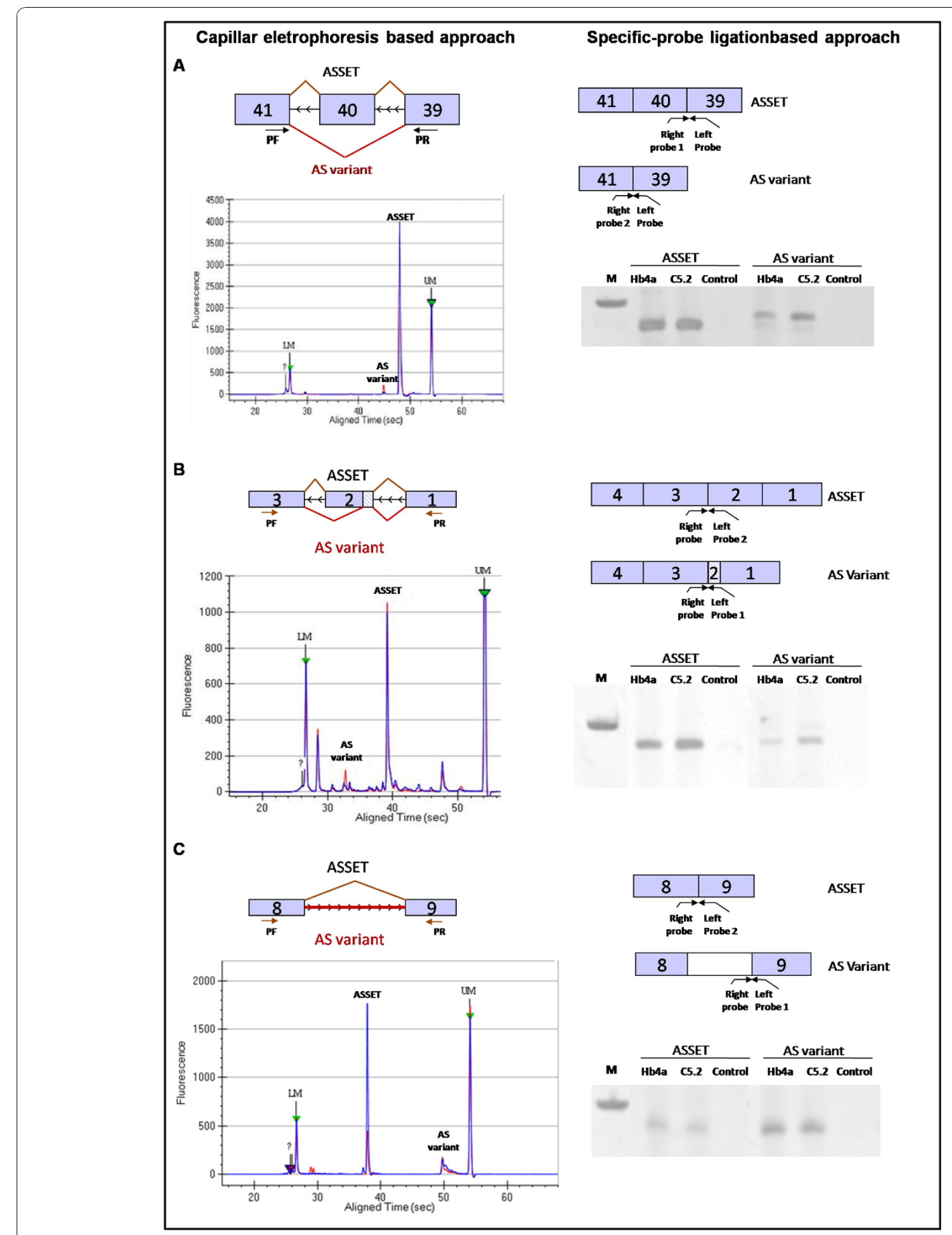

Figure 6 The influence of ERBB2-mediated expression on the regulation of AS variants. In the left panel, a schema of the microfluidic capillary electrophoresis approach is shown. The exons are represented by numbered squares according to the exons involved in the AS events for each gene. The black arrows represent the primers used for PCR amplification (PF - forward primer; PR - reverse primer). The electropherogram represents the amplification of the AS variants for the Hb4a cell line (blue line) and for the C5.2 cell line (red line). The green arrows indicates internal markers: LM (lower marker) and UM (upper marker). In the right panel, the probe-ligation approach is shown. Each pair of probe is shown for each AS variant separately, with the corresponding PCR products on $8 \%$ acrylamide gel. M - 100 bp ladder. A - gene, $B$ - FLNA and C -TRIP6. 
Table 6 Gene expression analysis under the influence of ERBB2 over-expression

\begin{tabular}{|c|c|c|c|c|c|c|c|}
\hline Gene Symbol & Cell line & Variant & Size (bp) & Concentration (ng/ul) & Normalized Concentration & ASSET/ Variant & $\mathrm{C} 5.2 / \mathrm{Hb} 4 \mathrm{a}$ \\
\hline \multirow[t]{4}{*}{ SFRS9 } & $\mathrm{Hb} 4 \mathrm{a}$ & ASSET & 232 & 6.5 & 3.7 & 36.2 & -4.8 \\
\hline & & variant & 100 & 0.2 & 0.1 & & \\
\hline & C5.2 & ASSET & 232 & 6.4 & 2.9 & 7.5 & \\
\hline & & variant & 100 & 0.9 & 0.4 & & \\
\hline \multirow[t]{4}{*}{ FLNA } & $\mathrm{Hb} 4 \mathrm{a}$ & ASSET & 500 & 24.9 & 14.1 & 95.7 & -4.8 \\
\hline & & variant & 377 & 0.3 & 0.2 & & \\
\hline & C5.2 & ASSET & 500 & 23.0 & 10.4 & 20.0 & \\
\hline & & variant & 377 & 1.2 & 0.5 & & \\
\hline \multirow[t]{4}{*}{ ALDH3A2 } & $\mathrm{Hb} 4 \mathrm{a}$ & ASSET & 470 & 20.0 & 11.4 & 10.0 & 1.0 \\
\hline & & variant & 610 & 2.0 & 1.1 & & \\
\hline & C5.2 & ASSET & 470 & 24.6 & 11.0 & 10.3 & \\
\hline & & variant & 610 & 2.4 & 1.0 & & \\
\hline \multirow[t]{4}{*}{ TRIP6 } & $\mathrm{Hb} 4 \mathrm{a}$ & ASSET & 203 & 12.6 & 7.2 & 8.9 & -3.4 \\
\hline & & variant & 636 & 1.4 & 0.8 & & \\
\hline & C5.2 & ASSET & 203 & 3.5 & 1.6 & 2.6 & \\
\hline & & variant & 636 & 1.3 & 0.6 & & \\
\hline \multirow[t]{4}{*}{ PTPLA } & $\mathrm{Hb} 4 \mathrm{a}$ & ASSET & 324 & 10.8 & 6.1 & 83.1 & 1.2 \\
\hline & & variant & 456 & 0.1 & 0.1 & & \\
\hline & C5.2 & ASSET & 324 & 16.8 & 7.5 & 98.4 & \\
\hline & & variant & 456 & 0.2 & 0.1 & & \\
\hline \multirow[t]{4}{*}{ RPS2 } & $\mathrm{Hb} 4 \mathrm{a}$ & ASSET & 187 & 13.7 & 7.8 & 1.4 & 1.1 \\
\hline & & variant & 390 & 12.2 & 5.5 & & \\
\hline & C5.2 & ASSET & 187 & 1.8 & 1.0 & 1.6 & \\
\hline & & variant & 390 & 1.4 & 0.6 & & \\
\hline
\end{tabular}

FLNA is a member of the actin-binding protein family that organizes actin filaments and is involved in numerous cellular processes, especially development. Many studies have reported the involvement of this protein in carcinogenesis. Using melanoma cell lines lacking or expressing FLNA, Fiori and collaborators [47] have shown that this protein is an important regulator of EGFR members (including ERBB2) that ensure efficient ligand-mediated activation of these receptors and, consequently, intracellular trafficking and degradation.

SFRS9 is a RNA-binding protein from the arginine/ serine-rich family that acts as a splicing factor regulating constitutive splicing and also modulating the selection of alternative splice sites. It has been suggested that this protein acts downstream of the ERBB2 pathway, since phosphorylation of SFRS9 was detected in ERBB2-over expressing breast and ovarian cancer cells and was reduced by monoclonal antibody Herceptin treatment. Moreover, a putative role for SFRS9 in cell migration was suggested, since migration was significantly retarded following the depletion of SFRS9 transcripts in ovarian cancer cell lines [48].

TRIP6 is a thyroid hormone receptor interactor that localizes to focal adhesion sites and along actin stress fibers $[49,50]$. This protein enhances lysophosphatidic acid (LPA) -induced cell migration by directly binding to the carboxyl-terminal tail of the LPA2 receptor through its LIM domains [51]. Moreover, TRIP6 might enhance cell migration by binding to PDZ domain of MAGI-1b/PTEN destabilizing membrane $\beta$-catenin and E-cadherin junctional complexes, promoting cell motility [52].

The development of strategies to selectively represent the AS transcripts repertoire, requiring small amounts of total RNA, will be important for generating more correlated information between AS transcripts and specific cell types and conditions in a transcriptome-wide format.

In spite of using Sanger sequencing in this study, our approach is completely suitable for using with next-generation sequencers [53], with the possibility of decreasing the number of PCR cycles, and consequently the redundancy level of the library; and assaying multiple barcoded samples with high sequence coverage in a single run. Finally, the use of next generation sequencers would tremendously expand the applicability of our approach toward characterizing cancer cell transcriptome diversity resulting from AS.

\section{Conclusions}

In this study we presented a method for exploring AS from any RNA source that generates reliable AS data in 
a transcriptome-wide format. Additionally, our data identified AS transcript candidates whose expression was influenced by ERBB2-mediated expression and can be tested as molecular markers for breast cancer. The association of such methodology with deep sequencing may be helpful for completely deciphering the cancer cell transcriptome and finding more precise molecular markers.

\section{Methods \\ Samples}

The human breast cell line C5.2 is derived from normal luminal cells transfected with four copies of the fulllength ERBB2 cDNA (HER-2/neu) gene presenting tumor characteristics [42]. Cells were maintained in RPMI medium supplemented with $100 \mathrm{ml} / \mathrm{l}$ fetal bovine serum (FBS), $5 \mu \mathrm{g} / \mathrm{ml}$ insulin, $5 \mu \mathrm{g} / \mathrm{ml}$ hydrocortisone and $1 \mathrm{mmol} / \mathrm{l} \mathrm{L}$-glutamine in a humidified incubator containing $50 \mathrm{ml} / \mathrm{l} \mathrm{CO}_{2}$ at $37^{\circ} \mathrm{C}$. The medium was changed every 2-3 days, and after 10 days the total RNA was extracted using a $\mathrm{CsCl}$ gradient [54]. The yield of extracted total RNA was determined with a Kontron 810 spectrophotometer GeneQuant pro (GE Healthcare Life Sciences), and the integrity was also verified by electrophoresis through 1\% agarose gel upon visualization with ethidium bromide.

RNA samples from 5 ductal breast carcinoma samples used in this study were provided by the biorepository bank from A.C. Camargo Hospital (São Paulo, Brazil). These samples were positive for ERBB2 through immunohistochemistry analysis (Table 6), according to the following criteria: weak to moderate complete membrane staining in $>10 \%$ of tumor cells or strong complete membrane staining in $>30 \%$ of tumor cells.

\section{Alternative splicing enriched cDNA library construction}

\section{RNA amplification and double strand CDNA synthesis}

For first strand cDNA synthesis, total RNA was incubated with $0.75 \mu \mathrm{g}$ oligo dT containing the T7 RNA polymerase site (5'AAACGACGGCCAGTGAATTGTAATACGACTCACTATAGGCGCT(24)' 3 ') at $70^{\circ} \mathrm{C}$ for 10 minutes. The reaction was performed by adding $1 \mathrm{X}$ first strand buffer, 0.01 M DTT (Dithiothreitol), $40 \mathrm{U}$ of RNasin (Promega Corporation), $1 \mathrm{mM}$ dNTP (GE Healthcare Life Sciences), $1 \mu \mathrm{g}$ of Template Switch (TS) DNA Oligo (5'AAGCAGTGGTAACAACGCAGAGTACGCGGG 3') and 400 U of SuperScript II (Invitrogen Life Technologies) in a total volume of $20 \mu \mathrm{l}$. The reaction was incubated for $120 \mathrm{~min}$ at $42^{\circ} \mathrm{C}$. For the second strand synthesis, the Advantage ${ }^{\circ}$ cDNA PCR Kit (Clontech) was used as follows: 5X cDNA PCR Reaction Buffer, $1 \mathrm{mM}$ dNTP Mix, 5X Advantage cDNA Polymerase Mix, 1.4 U of RNase $\mathrm{H}$ (Invitrogen Life
Technologies) in a final volume of $100 \mu \mathrm{l}$. The reaction was incubated at $37^{\circ} \mathrm{C}$ for $10 \mathrm{~min}, 94^{\circ} \mathrm{C}$ for $3 \mathrm{~min}, 65^{\circ} \mathrm{C}$ for $5 \mathrm{~min}$. and $75^{\circ} \mathrm{C}$ for $30 \mathrm{~min}$. The stop reaction including $0.25 \mathrm{M}$ of $\mathrm{NaOH}$ and $0.5 \mathrm{mM}$ EDTA was added, followed by incubation at $65^{\circ} \mathrm{C}$ for $10 \mathrm{~min}$. The dscDNA was purified by phenol:chloroform:isoamylic alcohol (25:24:1) pH 8.0 extraction followed by Microcon YM-100 Centrifugal Filter Unit (Millipore).

Double-strand cDNA was in vitro transcribed into RNA with RiboMAX ${ }^{\mathrm{m}}$ Large Scale RNA Production Systems (Promega Corporation) as follows: $1 \mathrm{X}$ buffer, $3 \mu \mathrm{M}$ rNTP and $2.5 \mu$ l Enzyme T7 Mix. The reaction was incubated at $37^{\circ} \mathrm{C}$ for 6 hours. Amplified RNA (aRNA) was purified by TRIzol $^{\circ}$ Reagent (Sigma Aldrich Corporation).

After purification, aRNA was used for double-stranded cDNA synthesis as described above using $1 \mu \mathrm{g}$ of TSoligo for the first strand synthesis and $0.5 \mu \mathrm{g}$ oligo $\mathrm{dT}$ (24) for the second strand synthesis.

\section{Denaturation and renaturation}

Double-stranded cDNA molecules were heated at $96^{\circ} \mathrm{C}$ for $20 \mathrm{~min}$ and incubated at $42^{\circ} \mathrm{C}$ for 24 hours in a mixture of $0.2 \%$ SDS, $0.5 \mathrm{M} \mathrm{NaCl}, 0.05 \mathrm{M}$ Tris- $\mathrm{HCl} \mathrm{pH} 7.5$ and $30 \%$ formamide.

\section{Exonuclease VII cleavage}

Exonuclease VII (USB Corporation) cleavage was performed in $70 \mathrm{mM}$ Tris-HCI, $\mathrm{pH}$ 8.0; 8 mM EDTA, $\mathrm{pH}$ 8.0; $10 \mathrm{mM} \mathrm{2-mercaptoethanol;} 50 \mu \mathrm{g} / \mathrm{ml} \mathrm{BSA}$ and 0.2 $\mathrm{U}$ of the enzyme and incubated at $37^{\circ} \mathrm{C}$ for $30 \mathrm{~min}$. The enzyme was inactivated at $95^{\circ} \mathrm{C}$ for $10 \mathrm{~min}$.

\section{Dpnll digestion}

Fifteen units of the restriction enzyme II (New England Biolabs) was used for each $500 \mathrm{ng}$ of cDNA in 1X buffer. The reaction was incubated at $37^{\circ} \mathrm{C}$ for 3 hours.

\section{Heteroduplex molecule trapping by biotin-streptavidin}

The cDNA sample was incubated with 100 pmoles of random 25-mer oligonucleotide biotinilated at the 5' end in 6X SSC and $0.1 \%$ SDS at $65{ }^{\circ} \mathrm{C}$ for 16 hours.

This mixture was incubated with $1 \mathrm{mg}$ streptavidin magnetic particles (F. Hoffmann-La Roche Ltd.) and 300 $\mu \mathrm{l}$ TEN100 binding buffer $(10 \mathrm{mM}$ Tris- $\mathrm{HCl} ; 1 \mathrm{mM}$ EDTA; $100 \mathrm{mM} \mathrm{NaCl}, \mathrm{pH}$ 7.5) for $30 \mathrm{~min}$ at room temperature. The tube was applied to a magnetic separator, and the supernatant was removed and incubated with another aliquot of streptavidin magnetic particle for a second round of purification. Both aliquots of magnetic particles coupled to heteroduplex molecules by the biotinilated random oligonucleotide were mixed and washed 3 times with TEN100 washing buffer $(10 \mathrm{mM}$ Tris-HCl; $1 \mathrm{mM}$ EDTA; $1 \mathrm{M} \mathrm{NaCl}, \mathrm{pH}$ 7.5). The cDNA 
molecules were then eluted from the magnetic particles by adding $6 \mathrm{M}$ guanidine- $\mathrm{HCl}$ and purified by a phenol: chloroform: isoamylic alcohol pH 8.0 extraction.

\section{Ligation of XDPN12 and XDPN14 adaptors}

The adaptors were commercially synthesized and contained four bases complementary to the cleavage site of the DpnII enzyme. First, the cDNA molecules were mixed with 1X T4 Ligase Buffer, 400 pmols XDPN12 (5'GATCTCTCGAGT3') and 400 pmols XDPN14 ( $5^{\prime}$ CTGATCACTCGAGA3') and incubated at $55^{\circ} \mathrm{C}$ for $1 \mathrm{~min}$. Next, the temperature was decreased from $54^{\circ} \mathrm{C}$ to $28^{\circ} \mathrm{C}$ at a rate of $2^{\circ} \mathrm{C}$ every $2 \mathrm{~min}$ and from $28^{\circ} \mathrm{C}$ to $14^{\circ} \mathrm{C}$ at a rate of $2^{\circ} \mathrm{C}$ every $4 \mathrm{~min}$ to favor a perfect annealing of the oligonucleotides. At last, 2000 units of T4 DNA ligase (Invitrogen Life Technologies) were added, and the reaction was incubated at $14^{\circ} \mathrm{C}$ for 16 hours. The reaction was purified with a Microcon YM-100 Centrifugal Filter Unit (Millipore).

\section{Polymerase chain reaction}

The RT-PCR reaction was carried out in $1 \mathrm{X}$ buffer, 0.1 mM dNTP, 1.5 mM MgCl2, 200 pmols XDPN18 oligonucleotide (5'CTGATCACTCGAGAGATC3'), 2 units $\mathrm{GoTaq}^{\circ}$ DNA Polymerase (Promega Corporation) and $10 \mu \mathrm{l}$ of purified cDNA in a total volume of $20 \mu \mathrm{l}$. The reaction was incubated at $95^{\circ} \mathrm{C}$ for $4 \mathrm{~min}$ followed by 35 cycles of $95^{\circ} \mathrm{C}$ for $45 \mathrm{~s}, 58^{\circ} \mathrm{C}$ for $1 \mathrm{~min}$ and $72^{\circ} \mathrm{C}$ for 4 min and a final extension at $72^{\circ}$ for $7 \mathrm{~min}$.

\section{Cloning and sequencing}

PCR products were inserted into T/A plasmid vector pTZ57R/T using the InsT/Aclone PCR Product Cloning Kit (Fermentas Life Sciences), following the manufacturer's recommendations, in a total volume of $10 \mu \mathrm{l}$. The ligation was performed at $22^{\circ} \mathrm{C}$ for 16 hours. The ligation was dialyzed for $20 \mathrm{~min}$ in $0.025 \mu \mathrm{M}$ nitrocellulose membrane (Millipore), and $3 \mu \mathrm{l}$ was used for transformation in DH10B E. coli cells by electroporation $(2.5 \mathrm{KV}, 25$ $\mu F D, 200$ OHMS). The clone inserts were sequenced with ABI Prism 3100 (Applied Biosystems). The sequencing reaction was performed with M13 reverse primer (5'GTCATAGCTGTTTCCTG3') and BigDye Terminator v3.1 cycle sequencing kit (Applied Biosystems), following the manufacturer's recommendations.

\section{Bioinformatics analysis}

The sequences were automatically analyzed, and regions corresponding to vector sequences were trimmed. The quality control was performed in $20 \mathrm{bp}$ windows, where only windows containing at least $15 \mathrm{bp}$ with a Phrep quality score $\geq 20$ were considered.

The sequences of each library were clustered individually using the CAP3 program, allowing estimation of library's redundancy. The consensus sequences were first aligned against the human genome (NCBI build \#36.1) using BLAT [29]. Second, to improve the quality and specificity of alignment the best hit of each sequence in the genome was selected, and realigned using Sim4 [30]. Third, sequences showing identity $\geq$ 93\% and sequence coverage (percentage of sequence length aligned) $\geq 55 \%$ were considered. Lastly, the sequences were clustered with ESTs from dbEST (8,133,299 sequences), mRNAs (244,284 sequences) and RefSeqs (26,040 sequences) downloaded from UCSC (September 2007) (see Galante [55] for more details).

\section{RT-PCR validation}

The primers for splice variant validation were designed at the extremities of the ASSET sequence. Twenty nanograms of cDNA from both the total RNA from the C5.2 cell line and the pool of breast cancer samples were used to validate the ASSETs from Lib_1 and Lib_2, respectively. The PCR reaction was performed in a total volume of $20 \mu \mathrm{l}$ by mixing $1 \mathrm{X}$ reaction buffer (Invitrogen Life Technologies), $2.5 \mathrm{mM} \mathrm{MgCl}_{2}$ (Invitrogen Life Technologies), $0.2 \mathrm{mM}$ dNTP (Amersham Biosciences), 10 pmoles of each primer and 1 unit Taq Platinum (Invitrogen Life Technologies). PCR reactions were performed with 40 cycles at $95^{\circ} \mathrm{C}$ for $30 \mathrm{sec}, 60^{\circ} \mathrm{C}$ for 30 sec and $72^{\circ} \mathrm{C}$ for $30 \mathrm{sec}$, followed by a final extension at $72^{\circ} \mathrm{C}$ for $7 \mathrm{~min}$. Amplification products were visualized on a $8 \%$ acrylamide gel and subsequently sequenced by ABI3130.

\section{$E R B B 2$ influence on relative expression}

For verifying the $E R B B 2$ influence on gene expression, all ASSETs were amplified using the C5.2 cell line and also the Hb4a cell line, which is a human mammary luminal epithelial cell line. The PCR products were quantified through capillary microfluidic electrophoresis (LabChip GX - Caliper Lifesciences). The expression of the GAPDH gene was used as a normalization factor. The expression ratio was determined by the normalized value of $\mathrm{C} 5.2$ divided by the normalized value of $\mathrm{Hb} 4 \mathrm{a}$ for each ASSET. Genes were considered to be differently expressed between cell lines for ratios $\geq|2|$. The differently expressed genes were analyzed in a group of tumor and normal breast samples through a strategy based on specific-probe ligation. The left and right probes were targeted against specific exon junctions of each variant of a gene. The left probe contained at its 5' end a recognition sequence of the forward PCR primer (GGGTAGGCTAAGGGTAGGA) followed by a stuffer sequence of 38 nucleotides (CCGTTGCCAGTCTGCTCAGACCTCCCTCGCGCCATCAG), and the right probe was phosphorylated at its $5^{\prime}$ end and contained a recognition sequence of the reverse PCR primer 
(TCTAGATTGGATCTTGCTGGCAC) at its 3' end. A specific RT primer designed downstream of the probe target sequence was used for cDNA synthesis. The probes were hybridized to pre-heated cDNA from $\mathrm{Hb} 4 \mathrm{a}$ and $\mathrm{C} 5.2$ at $60^{\circ} \mathrm{C}$ overnight, and only the probes specifically hybridized to their target sequences were connected by T4 DNA ligase, resulting in one unique probe. As a negative control, ligation and hybridization were performed in the absence of any template for all pairs of probes. The unique probes were PCR amplified. Amplification products were analyzed on $8 \%$ acrylamide gel. (Additional file 1).

\section{Additional material}

Additional File 1: Gene expression analysis under the influence of ERBB2 over-expression.

\section{List of abbreviations used}

AS: alternative splicing; ASSET: alternative splicing sequence-enriched tag; dscDNA: double-stranded CDNA; EST; expressed sequence tag; RT-PCR: reverse transcriptase polymerase chain reaction; TS-oligo: Template Switch oligo

\section{Acknowledgements}

This work was supported by Fundação de Amparo à Pesquisa do Estado de São Paulo (CEPID/FAPESP 98/14335). ENF is supported by grant FAPESP (05/ 56289-2). We are grateful to the Biobank and the Research and Educational Center at A.C. Camargo Hospital. We thank Dr. Ricardo Renzo Brentani for important comments and corrections on the manuscript.

This article has been published as part of BMC Genomics Volume 11 Supplement 5, 2010: Proceedings of the 5th International Conference of the Brazilian Association for Bioinformatics and Computational Biology. The full contents of the supplement are available online at http://www. biomedcentral.com/1471-2164/11?issue=S5

\section{Author details}

${ }^{1}$ Laboratory of Genomics and Molecular Biology, Hospital A.C. Camargo, Fundação Antonio Prudente, São Paulo, 01509-900, Brazil. 'Department of Genetics and Evolutionary Biology, Institute of Biosciences University of São Paulo, São Paulo, 05508-090, Brazil. 'Laboratory of Computational Biology, Ludwig Institute for Cancer Research, São Paulo, 01323-903, Brazil.

\section{Authors' contributions}

ENF designed the study, carried out all wet lab assays and wrote the manuscript. MCRR participated in the design of the study and helped with the construction of the libraries. PAG and JES performed the bioinformatics analysis. GCM participated in the validation experiments. SJS conceived the study and coordinated the bioinformatics analysis. DMC conceived, designed and coordinated the study and wrote the manuscript.

\section{Competing interests}

The authors declare that they have no competing interests.

Published: 22 December 2010

\section{References}

1. Gilbert W: Why genes in pieces? Nature 1978, 271:501-.

2. Pan $Q$, Shai O, Lee LJ, Frey BJ, Blencowe BJ: Deep surveying of alternative splicing complexity in the human transcriptome by high-throughput sequencing. Nat Genet. 2008, 40:1413-1415.
3. Wang ET, Sandberg R, Luo S, Khrebtukova I, Zhang L, Mayr C, Kingsmore SF, Schroth GP, Burge CB: Alternative isoform regulation in human tissue transcriptomes. Nature 2008, 456:470-476.

4. Harrow J, Denoeud F, Frankish A, Reymond A, Chen CK, Chrast J, Lagarde J, Gilbert JG, Storey R, Swarbreck D, Rossier C, Ucla C, Hubbard T,

Antonarakis SE, Guigo R: GENCODE: producing a reference annotation for ENCODE. Genome Biol. 2006, 7:1-9.

5. Zavolan M, Van Nimwegen E: The types and prevalence of alternative splice forms. Curr. Opin. Struct. Biol. 2006, 16:362-367.

6. Black DL: Mechanisms of alternative pre-messenger RNA splicing. Annu Rev Biochem 2003, 72:291-336.

7. Yura K, Shionyu M, Hagino K, Hijikata A, Hirashima Y, Nakahara T, Eguchi T, Shinoda K, Yamaguchi A, Takahashi K, Itoh T, Imanishi T, Gojobori T, Mitiko : Alternative splicing in human transcriptome: functional and structural influence on proteins. Gene 2006, 380:63-71.

8. Xing Y, Lee C: Relating alternative splicing to proteome complexity and genome evolution. Adv Exp Med Biol 2007, 623:36-49.

9. Tazi J, Bakkour N, Stamm S: Alternative splicing and disease. Biochim Biophys Acta. 2009, 1792:14-26.

10. Bartel F, Taubert $H$, Harris LC: Alternative and aberrant splicing of MDM2 mRNA in human cancer. Cancer Cell 2002, 2:9-15.

11. Hui L, Zhang $X$, Wu $X$, Lin Z, Wang Q, Li Y, Hu G: Identification of alternatively spliced mRNA variants related to cancers by genome-wide ESTs alignment. Oncogene 2004, 23:3013-3023.

12. Venables JP, Klinck R, Koh C, Gervais-Bird J, Bramard A, Inkel L, Durand M, Couture S, Froehlich U, Lapointe E, Lucier JF, Thibault P, Rancourt C, Tremblay K, Prinos P, Chabot B, Elela SA: Cancer-associated regulation of alternative splicing. Nat Struct Mol Biol 2009, 16:670-676.

13. Venables JP, Klinck R, Bramard A, Inkel L, Dufresne-Martin G, Koh C, GervaisBird J, Lapointe E, Froehlich U, Durand M, Gendron D, Brosseau JP, Thibault P, Lucier JF, Tremblay K, Prinos P, Wellinger RJ, Chabot B, Rancourt C, Elela SA: Identification of alternative splicing markers for breast cancer. Cancer Res 2008, 68:9525-9531.

14. Brinkman BMN: Splice variants as cancer biomarkers. Clinical Biochemistry 2004, 37:584-594.

15. Hsu FR, Chang HY, Lin YL, Tsai YT, Peng HL, Chen YT, Cheng CY, Shih MY, Liu CH, Chen CF: AVATAR: a database for genome-wide alternative splicing event detection using large scale ESTs and mRNAs. Bioinformation 2005, 1:16-8.

16. Modrek B, Resch A, Grasso C, Lee C: Genome-wide detection of alternative splicing in expressed sequences of human genes. Nucleic Acids Res. 2001, 29:2850-2859.

17. Kirschbaum-Slager N, Parmigiani RB, Camargo AA, de Souza SJ: Identification of human exons overexpressed in tumors through the use of genome and expressed sequence data. Physiol. Genomics 2005, 21:423-432.

18. Kan Z, Rouchka EC, Gish WR: Gene structure prediction and alternative splicing analysis using genomically aligned ESTs. Genome Res. 2001, 5:889-900.

19. Chen FC, Chen CJ, Ho JY, Huang TJ: Identificatyion and evolutionary analysis of novel exons and alternative splicing events using crossspecies EST-to-genome comparisons in human, mouse and rat. BMC Bioinformatics 2006, 7:136.

20. Johnson JM, Castle J, Garrett-Engele P, Kan Z, Loerch PM, Armour CD, Santos R, Schadt EE, Stoughton R, Shoemaker DD: Genome-wide survey of human alternative pre-mRNA splicing with exon junction microarrays. Science 2003, 302:2141-2144.

21. Gardina PJ, Clark TA, Shimada B, Staples MK, Yang Q, Veitch J, Schweitzer A, Awad T, Sugnet C, Dee S, Davies C, Williams A, Turpaz Y: Alternative splicing and differential gene expression in colon cancer detected by a whole genome exon array. BMC Genomics 2006, 7:325.

22. Cuperlovic-Culf M, Belacel N, Culf AS, Ouellette RJ: Microarray analysis of alternative splicing. OMICS 2006, 10:344-357.

23. Castle JC, Zhang C, Shah JK, Kulkarni AV, Kalsotra A, Cooper TA, Johnson JM: Expression of 24,426 human alternative splicing events and predicted cis regulation in 48 tissues and cell lines. Nat Genet 2008, 40:1416-1425.

24. Ferreira EN, Rangel MC, Pineda PB, Vidal DO, Camargo AA, Souza SJ, Carraro DM: Heteroduplex formation and S1 digestion for mapping alternative splicing sites. Genet Mol Res 2008, 7:958-969. 
25. Watahiki A, Waki K, Hayatsu N, Shiraki T, Kondo S, Nakamura M, Sasaki D, Arakawa T, Kawai J, Harbers M, Hayashizaki Y, Carninci P: Libraries enriched for alternatively spliced exons reveal splicing patterns in melanocytes and melanomas. Nat Methods 2004, 3:233-239.

26. Thill G, Casteli V, Pallud S, Salanoubat M, Wincker $P$, de la Grange $P$, Auboet D, Schachter V, Weissenbach J: ASEtrap: a biological method for speeding up the exploration of spliceomes. Genome Res. 2006, 16:776-786.

27. Matz M, Shagin D, Bogdanova E, Britanova O, Lukyanov S, Diatchenko L, Chenchik A: Amplification of CDNA ends based on template-switching effect and step-out PCR. Nucleic Acids Res. 1999, 27:1558-1560.

28. Huang $X$, Madan A: CAP3: A DNA sequence assembly program. Genome Res. 1999, 9:868-877.

29. Kent WJ, Sugnet CW, Furey TS, Roskin KM, Pringle TH, Zahler AM, Haussler D: The human genome browser at UCSC. Genome Res. 2002, 12:996-1006.

30. Florea L, Hartzell G, Zhang Z, Rubin GM, Miller W: A computer program for aligning a cDNA sequence with a genomic DNA sequence. Genome Res. 1998, 9:967-974.

31. Maere S, Heymans K, Kuiper M: BiNGO: a Cytoscape plugin to assess overrepresentation of Gene Ontology categories in biological networks. Bioinformatics 2005, 21:3448-3449.

32. Lewis BP, Green RE, Brenner SE: Evidence for the widespread coupling of alternative splicing and nonsense-mediated mRNA decay in humans. Proc Natl Acad Sci U S A 2003, 7:189-192.

33. Green RE, Lewis BP, Hillman RT, Blanchette M, Lareau LF, Garnett AT, Rio DC, Brenner SE: Widespread predicted nonsense-mediated mRNA decay of alternatively-spliced transcripts of human normal and disease genes. Bioinformatics 2003, 19:1118-21.

34. Venables JP, Koh CS, Froehlich U, Lapointe E, Couture S, Inkel L, Bramard A, Paquet ER, Watier V, Durand M, Lucier JF, Gervais-Bird J, Tremblay K, Prinos $P$, Klinck R, Elela SA, Chabot B: Multiple and specific mRNA processing targets for the major human hnRNP proteins. Mol Cell Biol 2008, 28:6033-6043.

35. Nardi A, Pomari E, Zambon D, Belvedere P, Colombo L, Dalla Valle L: Transcriptional control of human steroid sulfatase. J Steroid Biochem Mol Biol 2009.

36. Jiang Z, Cote J, Kwon JM, Goate AM, Wu JY: Aberrant splicing of tau premRNA caused by intronic mutations associated with the inherited dementia frontotemporal dementia with Parkinson linked cromossome 17. Molecular and Cellular Biology 2000, 20:4036-4048.

37. Diatchenko L, Lau YF, Campbell AP, Chenchik A, Moqadam F, Huang B, Lukyanov S, Lukyanov K, Gurskaya N, Sverdlov ED, Siebert PD: Suppression subtractive hybridization: a method for generating differentially regulated or tissue-specific CDNA probes and libraries. Proc Natl Acad Sci US A 1996, 93:6025-6030.

38. Albanell J, Baselga J: Unraveling resistance to trastuzumab (Herceptin): insulin-like growth factor-I receptor, a new suspect. J Natl Cancer Inst 2001, 93:1830-183.

39. Slamon DJ, Leyland-Jones B, Shak S, Fuchs H, Paton V, Bajamonde A, Fleming T, Eiermann W, Wolter J, Pegram M, Baselga J, Norton L: Use of chemotherapy plus a monoclonal antibody against HER2 for metastatic breast cancer that overexpresses HER2. N Engl J Med 2001, 344:783-92.

40. Kumar CC, Madison V: Drugs targeted against protein kinases. Expert Opin Emerg Drugs 2001, 6:303-315.

41. Slamon D, Pegram M: Rationale for trastuzumab (Herceptin) in adjuvant breast cancer trials. Semin Oncol 2001, 28:13-19.

42. Harris RA, Eichholtz TJ, Hiles ID, Page MJ, O'Hare MJ: New model of ErbB-2 over-expression in human mammary luminal epithelial cells. Int $\mathrm{J}$ Cancer 1999, 80:477-484.

43. Press MF, Hung G, Godolphin W, Slamon DJ: Sensitivity of HER-2/neu antibodies in archival tissue samples: potential source of error in immunohistochemical studies of oncogene expression. Cancer Res. 1994, 54:2771-2777.

44. Stamps AC, Davies SC, Burman J, O'Hare MJ: Analysis of proviral integration in human mammary epithelial cell lines immortalized by retroviral infection with a temperature-sensitive SV40 T-antigen construct. Int. J. Cancer 1994, 57:865-874.

45. Jongeneel CV, Iseli C, Stevenson BJ, Riggins GJ, Lal A, Mackay A, Harris RA, O'Hare MJ, Neville AM, Simpson AJG, Strausberg RL: Comprehensive sampling of gene expression in human cell lines with massively parallel signature sequencing. PNAS 2003, 100:4701-4705.

46. dos Santos ML, Palanch CG, Salaorni S, Da Silva WA Jr, Nagai MA: Transcriptome characterization of human mammary cell lines expressing different levels of ERBB2 by serial analysis of gene expression. Int J Oncol. 2006, 28:1441-1461.

47. Fiori JL, Zhu TN, O'Connell MP, Hoek KS, Indig FE, Frank BP, Morris C, Kole S, Hasskamp J, Elias G, Weeraratna AT, Bernier M: Filamin A modulates kinase activation and intracellular trafficking of epidermal growth factor receptors in human melanoma cells. Endocrinology 2009, 150:2551-2560.

48. Mukherji M, Brill LM, Ficarro SB, Hampton GM, Schultz PG: A phosphoproteomic analysis of the ErbB2 receptor tyrosine kinase signaling pathways. Biochemistry 2006, 45:15529-15540.

49. Yi J, Beckerle MC: The human TRIP6 gene encodes a LIM domain protein and maps to chromosome $7 q 22$, a region associated with tumorigenesis. Genomics 1998, 49:314-316.

50. Wang Y, Dooher JE, Koedood Zhao M, Gilmore TD: Characterization of mouse Trip6: a putative intracellular signaling protein. Gene 1999, 234:403-409.

51. Xu J, Lai YJ, Lin WC, Lin FT: TRIP6 enhances lysophosphatidic acidinduced cell migration by interacting with the lysophosphatidic acid 2 receptor. J Biol Chem 2004, 279:10459-10468.

52. Chastre E, Abdessamad M, Kruglov A, Bruyneel E, Bracke M, Di Gioia Y, Beckerle MC, van Roy F, Kotelevets L: TRIP6, a novel molecular partner of the MAGl-1 scaffolding molecule, promotes invasiveness. FASEB J 2009, 23:916-928.

53. Holt RA, Jones SJ: The new paradigm of flow cell sequencing. Genome Res. 2008, 18:839-846.

54. Glisin V, Crkvenjakov R, Byus C: Ribonucleic acid isolated by cesium chloride centrifugation. Biochemistry 1974, 13:2633-2637.

55. Galante PA, Vidal DO, de Souza JE, Camargo AA, de Souza SJ: Senseantisense pairs in mammals: Functional and evolutionary considerations. Genome Biol. 2007, 8:R40.

doi:10.1186/1471-2164-11-S5-S4

Cite this article as: Ferreira et al:: Alternative splicing enriched cDNA libraries identify breast cancer-associated transcripts. BMC Genomics 2010 11(Suppl 5):S4.

\section{Submit your next manuscript to BioMed Central and take full advantage of:}

- Convenient online submission

- Thorough peer review

- No space constraints or color figure charges

- Immediate publication on acceptance

- Inclusion in PubMed, CAS, Scopus and Google Scholar

- Research which is freely available for redistribution

Submit your manuscript at www.biomedcentral.com/submit
C Biomed Central 